Prepared for the U.S. Department of Energy

under Contract DE-AC05-76RL01830

\title{
Neutron Screening Measurements of 110 gallon drums at T-Plant
}

AV Mozhayev

JR Hilliard

RK Berg

January 2011

Pacific Northwest

NATIONAL LABORATORY

Proudly Operated by Battelle Since 1965 


\title{
DISCLAIMER
}

This report was prepared as an account of work sponsored by an agency of the United States Government. Neither the United States Government nor any agency thereof, nor Battelle Memorial Institute, nor any of their employees, makes any warranty, express or implied, or assumes any legal liability or responsibility for the accuracy, completeness, or usefulness of any information, apparatus, product, or process disclosed, or represents that its use would not infringe privately owned rights. Reference herein to any specific commercial product, process, or service by trade name, trademark, manufacturer, or otherwise does not necessarily constitute or imply its endorsement, recommendation, or favoring by the United States Government or any agency thereof, or Battelle Memorial Institute. The views and opinions of authors expressed herein do not necessarily state or reflect those of the United States Government or any agency thereof.

\author{
PACIFIC NORTHWEST NATIONAL LABORATORY \\ operated by \\ BATTELLE \\ for the \\ UNITED STATES DEPARTMENT OF ENERGY \\ under Contract DE-AC05-76RL01830
}

Printed in the United States of America
Available to DOE and DOE contractors from the Office of Scientific and Technical Information,
P.O. Box 62, Oak Ridge, TN 37831-0062;
ph: (865) 576-8401
fax: $(865)$ 576-5728
email: reports@adonis.osti.gov

\begin{abstract}
Available to the public from the National Technical Information Service, U.S. Department of Commerce, 5285 Port Royal Rd., Springfield, VA 22161 ph: (800) 553-6847 fax: $(703) 605-6900$ email: orders@ntis.fedworld.gov online ordering: http://www.ntis.gov/ordering.htm
\end{abstract}

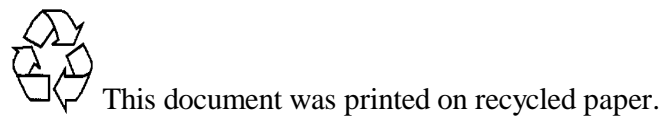




\title{
Neutron Screening Measurements of $\mathbf{1 1 0}$ gallon drums at T-Plant
}

\author{
AV Mozhayev \\ JR Hilliard \\ RK Berg
}

January 2011

Pacific Northwest National Laboratory

Richland, Washington 99352 


\section{Executive Summary}

The Pacific Northwest National Laboratory (PNNL) Nondestructive Assay (NDA) Service Center was contracted to develop and demonstrate a simple and inexpensive method of assaying 110 gallon drums at the Hanford Site's T-Plant. The drums contained "pucks" of crushed old drums used for storage of transuranic (TRU) waste. The drums were to be assayed to determine if they meet the criteria for TRU or Low Level Waste (LLW).

Because of the dense matrix (crushed steel drums) gamma measurement techniques were excluded and a mobile, configurable neutron system, consisting of four sequentially connected slab detectors was chosen to be used for this application. An optimum measurement configuration was determined through multiple test measurements with a californium source. Based on these measurements the initial calibration of the system was performed applying the isotopic composition for aged weapon-grade plutonium. A series of background and blank "puck" drum measurements allowed estimating detection limits for both total (singles) and coincidence (doubles) counting techniques. It was found that even conservative estimates for minimum detection concentration using singles count rate were lower than the essential threshold of 100 $\mathrm{nCi} / \mathrm{g}$. Whereas the detection limit of coincidence counting appeared to be about as twice as high of the threshold.

A series of measurements intended to verify the technique and revise the initial calibration obtained were performed at the Waste Receiving and Processing (WRAP) facility with plutonium standards. Standards with a total mass of $0.3 \mathrm{~g}$ of plutonium (which is estimated to be equivalent of $100 \mathrm{nCi} / \mathrm{g}$ for net waste weight of $300 \mathrm{~kg}$ ) loaded in the test "puck" drum were clearly detected. The ensuing measurements of higher plutonium loadings verified the calibration factors obtained in the initial exercise. The revised and established calibration factors were also confirmed within established uncertainties by additional measurements of plutonium standards in various locations in the test drum.

Due to necessity to dispense the blank "test" drum an alternative method of baseline determination was established during field measurements. Count rates of ambient background were corrected by the differences between observed background and blank "test" drum count rates which were previously determined over a series of measurements.

Only 31 drums out of 352 counted during the intensive measurement campaign at T-Plant were determined to be "Suspect TRU". 25 of these drums were re-measured at the WRAP facility using the SuperHENC. Of the 25 drums measured, 21 were confirmed to be TRU and the remaining four LLW. 


\section{Acronyms and Abbreviations}

$\begin{array}{ll}\text { AK } & \text { Accepted Knowledge } \\ \text { c/s } & \text { Counts per second } \\ \text { DE } & \text { Diatomaceous Earth } \\ \text { LLW } & \text { Low Level Waste } \\ \text { MDC } & \text { Minimal Detectable Concentration } \\ \text { MDL } & \text { Method Detection Limit } \\ \text { nCi } & \text { nanoCurie } \\ \text { NDA } & \text { Nondestructive Assay } \\ \text { NIST } & \text { National Institute of Standards and Technology } \\ \text { PNNL } & \text { Pacific Northwest National Laboratory } \\ \text { SuperHENC } & \text { Super High Efficiency Neutron Counter } \\ \text { TRU } & \text { Transuranic } \\ \text { WIPP } & \text { Waste Isolation Pilot Plant } \\ \text { WRAP } & \text { Waste Receiving and Processing Facility }\end{array}$




\section{Contents}

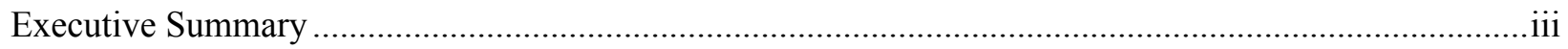

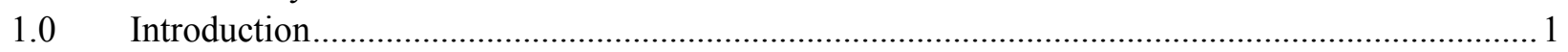

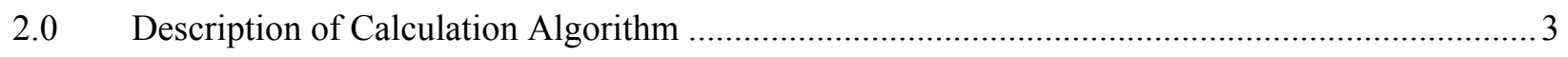

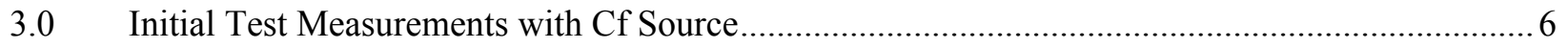

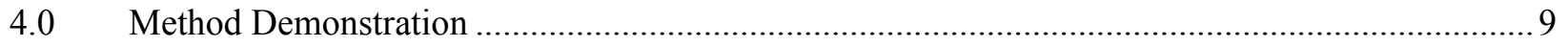

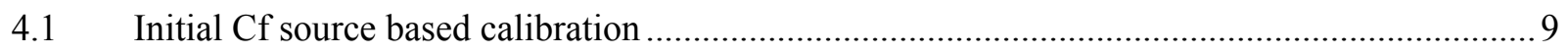

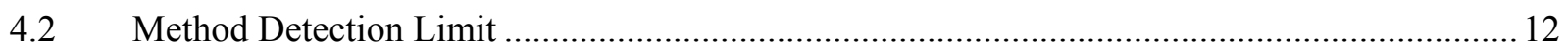

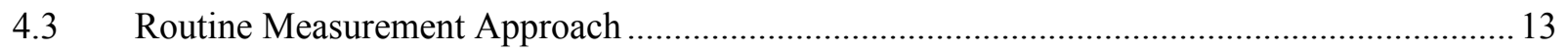

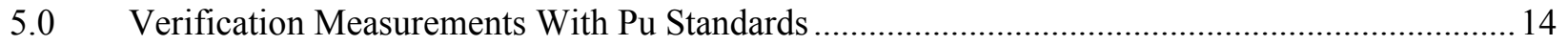

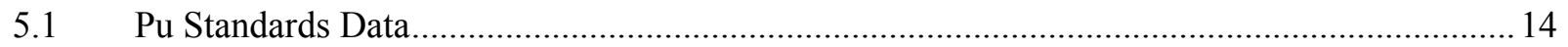

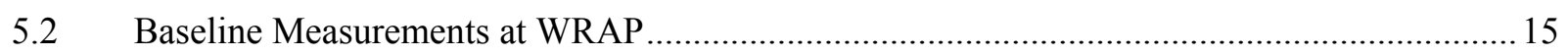

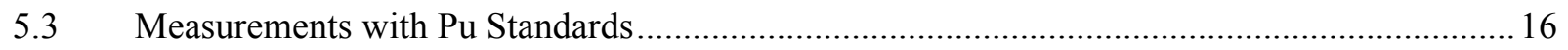

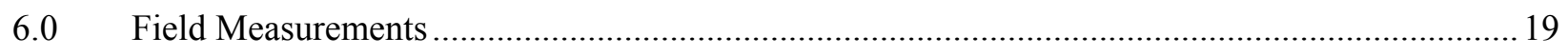

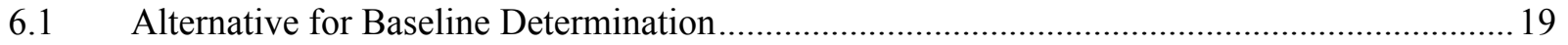

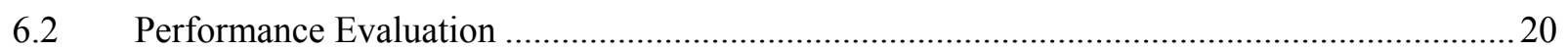

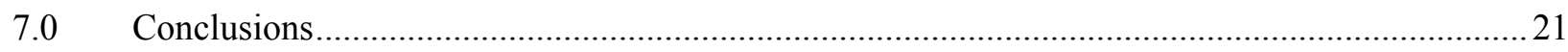

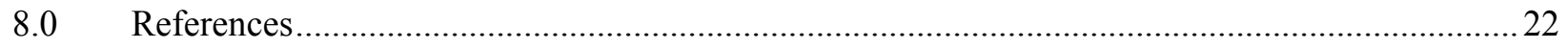




\section{Figures and Tables}

\section{Figures}

\begin{tabular}{|c|c|c|c|}
\hline Figure & 1.1 & Slabs in "Square" configuration & 1 \\
\hline Figure & 3.1 & Source positions in the test drum & 6 \\
\hline Figure & 3.2 & Measurements of the test drum with ${ }^{252} \mathrm{Cf}$ source inside & 7 \\
\hline Figure & 4.3 .1 & Drum Counting Positions & 13 \\
\hline Figure & 5.3 .1 & Singles Count Rate results & 17 \\
\hline Figure & 5.3 .2 & Doubles Count Rate results & 17 \\
\hline
\end{tabular}

\section{Tables}

Table $\quad 1.1 \quad$ Accepted Data of Plutonium Isotopic Composition $\quad 2$

Table $3.1 \quad$ Spatial responses for chosen 43" x 43" configuration $\quad 7$

Table $\quad 3.2 \quad$ Averaged spatial responses for chosen 43" x 43" configuration 8

Table $\quad 4.1 .1 \quad$ Calibration factors for singles and doubles based on ${ }^{252} \mathrm{Cf}$ measurements $\quad 10$

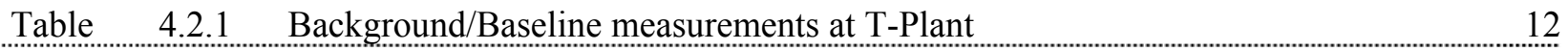

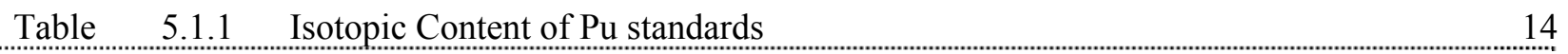

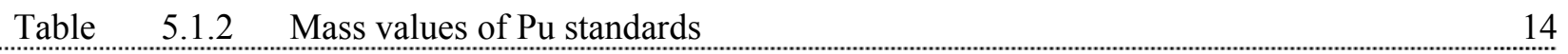

Table 5.2.1 Baseline count rates observed at WRAP during the test measurements $\quad 15$

Table $\quad 5.3 .1 \quad$ Results of measurements with Pu standards $\quad 16$

Table 5.3.2 Confirmation of Calibration factors revised $\quad 18$

Table $\quad 6.1 .1 \quad$ Difference between blank test drum and ambient background counts $\quad 19$

Table $\quad 6.2 .1 \quad$ Results of verification measurements with Pu standards $\quad 20$ 


\subsection{Introduction}

T-Plant uses a compactor to crush used empty 55 and 85 gallon drums which previously contained waste categorized as Transuranic ${ }^{\dagger}$ (TRU) and are contaminated to an unknown extent. Once crushed, the drum "pucks" are placed in a 110 gallon over pack drum for final disposal. The drums are to be assayed to determine if they meet the criteria for TRU or Low Level Waste (LLW) as defined in document [1].

Once classified as LLW drums may be then sent to the Hanford disposal site whereas the others classified as "Suspect TRU" are to be shipped to Waste Receiving and Processing (WRAP) Facility for the official characterization. If confirmed as TRU they are sent to the National Repository at Waste Isolation Pilot Plant (WIPP) in Carlsbad, NM, for final disposal. Because sorting the non-TRU drums at WRAP is extremely inefficient it was determined to perform initial screening of the 110 gallon "puck" drums at TPlant. Identification of the anticipated majority of non-TRU drums would reduce shipment evolutions and facility efforts.

The Pacific Northwest National Laboratory (PNNL) Nondestructive Assay (NDA) Service Center was contracted to develop and demonstrate a simple method of assaying the drums. Considering the bulk density of the "puck" drums, neutron measurements appeared to be the preferred counting method over any gamma assay techniques [2] for the given application. Although active interrogation neutron techniques $[3,4]$ could be more sensitive and accurate in the application, the required equipment is more sophisticated and substantial (and hence expensive) than those utilized for passive neutron methods [5]. Thus passive neutron counting was selected to be the most appropriate measurement technique and easiest to implement for this task.

The mobile, configurable neutron system was chosen to be used for this application. The system consists of four sequentially connected slab detectors operated by a computer-controlled neutron coincidence analyzer based on a shift register. Each slab comprises ten 4 -atm ${ }^{3} \mathrm{He}$ tubes embedded in a polyethylene block 32 inches tall and 25 inches wide. Depending on the size and shape of an object to be counted the slabs can be positioned in different configurations. The so called "square" configuration shown in Figure 1.1 is applied for measurements of drums and other relatively small objects. Distance between opposite banks of the slabs, "D", is defined by the size of an object. The slabs can be elevated by lift jacks up to 14 inches high from the ground level to help with profile as well as potential scattering effects from the ground surface.

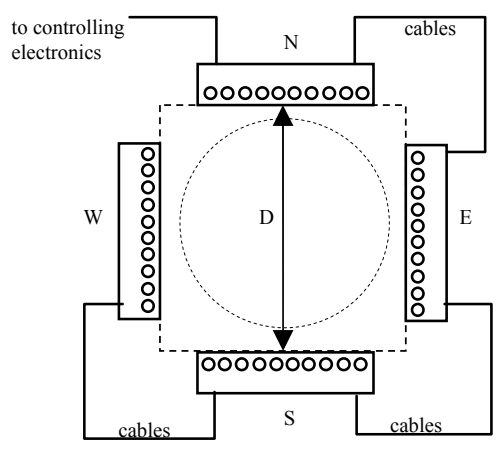

Figure 1.1. Slabs in "Square" configuration

\footnotetext{
${ }^{\dagger}$ Waste containing more than $100 \mathrm{nCi}$ of alpha-emitting isotopes with atomic number greater than 92 and with halflives greater than 20 years per gram of waste.
} 
An over pack 110 gallon drum filled with uncontaminated crushed drum pucks was specifically composed to simulate the matrix of the real drums and used for calibration and test exercises. Several source tubes were installed throughout the crushed drum pucks in the test drum to allow for the placement of radioactive sources at various heights and locations within the over pack.

A National Institute of Standards and Technology (NIST) traceable ${ }^{252} \mathrm{Cf}$ neutron source (identified as Cf2) was used for the initial calibration and testing exercises. A pallet with a turn table mounted on its top was manufactured to position the test drum during the exercises. Both total (singles) and coincidence (doubles) neutron counting techniques were tested.

Since a measured value of the isotopic distribution of material contained in a drum was impossible to obtain, the isotopic composition for aged weapon-grade plutonium was mutually agreed upon as accepted knowledge (AK) data (see Table 1.1) providing conservative estimates and were considered the "default" values unless the material isotopic composition could actually be measured and found to be different.

Table 1.1. Accepted Data of Plutonium Isotopic Composition

\begin{tabular}{|c|c|}
\hline Nuclide & wt $\%$ \\
\hline${ }^{238} \mathrm{Pu}$ & $0.03( \pm 10 \%)$ \\
${ }^{239} \mathrm{Pu}$ & $93.68( \pm 1 \%)$ \\
${ }^{240} \mathrm{Pu}$ & $6.05( \pm 5 \%)$ \\
${ }^{241} \mathrm{Pu}$ & $0.22( \pm 3 \%)$ \\
${ }^{242} \mathrm{Pu}$ & $0.02( \pm 30 \%)$ \\
${ }^{241} \mathrm{Am}$ & $0.50( \pm 3 \%)$ \\
\hline${ }^{240} \mathrm{Pu}$ eff ${ }^{\dagger}$ & \\
\hline & $6.16 \pm 0.30(4.9 \%)$ \\
\hline${ }^{T R U}$ Specific Activity $[\mathrm{Ci} / \mathrm{g}]$ & $0.094 \pm 0.002(2.4 \%)$ \\
\hline
\end{tabular}

${ }^{240} \mathrm{Pu}_{\text {eff }}$ (effective) is the mass of ${ }^{240} \mathrm{Pu}$ that would give the same neutron response as that obtained from all the even isotopes in the actual sample. 


\subsection{Description of Calculation Algorithm}

The background-corrected neutron count rate is proportional to the ${ }^{240} \mathrm{Pu}$ effective mass contained in an item under consideration. The relationship between count rate observed and ${ }^{240} \mathrm{Pu}_{\text {eff }}$ quantity can be obtained through calibration of the measurement system with NIST traceable plutonium standards and/or spontaneous fission neutron sources. For waste applications where total plutonium mass ranges below 100 grams a linear function is most often applicable as a calibration curve:

$$
C R=a+b \cdot{ }^{240} m_{e f f} \quad \text { or } \quad C R=b \cdot{ }^{240} m_{\text {eff }}
$$

where $C R \quad$ - count rate $[1 / \mathrm{s}]$;

${ }^{240} m_{\text {eff }}-{ }^{240} \mathrm{Pu}_{\text {eff }}$ mass [g];

$a, b \quad$ - intercept $[1 / \mathrm{s}]$ and slope $[1 /(\mathrm{s} \cdot \mathrm{g})]$ of fitted function, respectively.

Thus using the calibration factors the count rate obtained on an assayed drum can be converted to ${ }^{240} \mathrm{Pu}_{\text {eff }}$ mass as follows

$$
{ }^{240} m_{e f f}=(C R-a) / b \text { or }{ }^{240} m_{e f f}=C R / b
$$

with its associated uncertainty:

$$
\Delta\left({ }^{240} m_{\text {eff }}\right)={ }^{240} m_{\text {eff }} \cdot \sqrt{\left(\frac{\sigma_{m}}{{ }^{240} m_{e f f}}\right)^{2}+\left(\delta_{s}\right)^{2}}
$$

where $\delta_{S} \quad$ - relative systematic uncertainty of spatial detection efficiency;

$\sigma_{m} \quad$ - combined uncertainty of calibration and counting components

$\sigma_{m}=\sqrt{\frac{\sigma_{C R}^{2}+\sigma_{a}^{2}+\left({ }^{240} m_{e f f}\right)^{2} \sigma_{b}^{2}+2\left({ }^{240} m_{e f f}\right) \sigma_{a b}}{b^{2}}}$ or

$\sigma_{m}=\sqrt{\frac{\sigma_{C R}^{2}+\left({ }^{240} m_{e f f}\right)^{2} \sigma_{b}^{2}}{b^{2}}}$

$\sigma_{C R} \quad$ - count rate uncertainty;

$\sigma_{a} ; \sigma_{b}$ - errors of corresponding calibration factors;

$\sigma_{a b} \quad$ - covariance of calibration factors.

Uncertainties associated with ${ }^{240} \mathrm{Pu}_{\text {eff }}$ mass values of $\mathrm{Pu}$ standards are negligible comparing to others and therefore may be disregarded. 
Having determined ${ }^{240} \mathrm{Pu}_{\text {eff }}$ mass the total mass of plutonium can be found as

$$
m_{P u}={ }^{240} m_{e f f}{ }^{240} C_{e f f}
$$

and its associated uncertainty

$$
\Delta m_{P u}=m_{P u} \cdot \sqrt{\left(\frac{\Delta\left({ }^{240} m_{e f f}\right)}{m_{e f f}}\right)^{2}+\left(\frac{\Delta\left({ }^{240} C_{e f f}\right)}{{ }^{240} C_{e f f}}\right)^{2}}
$$

where ${ }^{240} C_{\text {eff }} \quad-{ }^{240} \mathrm{Pu}_{\text {eff }}$ content [wt $\%$ ]

$$
\Delta\left({ }^{240} C_{e f f}\right)-{ }^{240} \mathrm{Pu}_{\mathrm{eff}} \text { content uncertainty }[\mathrm{wt} \%] ;
$$

Then, TRU activity value is determined

$$
A_{T R U}=m_{P u} \cdot a_{T R U}
$$

and its uncertainty

$$
\Delta A_{T R U}=A_{T R U} \cdot \sqrt{\left(\frac{\Delta m_{P u}}{m_{P u}}\right)^{2}+\left(\frac{\Delta a_{T R U}}{a_{T R U}}\right)^{2}}
$$

where $a_{T R U} \quad$ - specific TRU activity $[\mathrm{Ci} /(\mathrm{g}$ of $\mathrm{Pu})]$

$\triangle a_{T R U}$ - specific TRU activity uncertainty [Ci/(g of $\left.\left.\mathrm{Pu}\right)\right]$.

Finally, TRU concentration is calculated based on net weight of the waste

$$
x_{T R U}=A_{T R U} / W_{N E T}
$$

and its uncertainty

$$
\Delta x_{T R U}=\Delta A_{T R U} / W_{N E T}
$$

where $\mathrm{W}_{\mathrm{NET}}$ - net weight of the waste

The weight uncertainty is considered negligible $(<0.5 \%)$ comparing to that of TRU activity value and hence may be disregarded in this calculation. 
The method detection limit is calculated based on the uncertainty of baseline count rate using the following simplified ${ }^{\sharp}$ version of formula from HASQARD document [6]

$$
M D L=4.65 \cdot \Delta C R_{b g r d} / b
$$

where $\Delta C R_{b g r d}$ - standard deviation of background count rate obtained with a blank "puck" drum in place;

$b-$ calibration function slope.

Original formula is MDL $=\left(2.71 / \mathrm{T}_{\text {bgrd }}+4.65 \cdot \Delta \mathrm{CR}_{\mathrm{bgrd}}\right) / \mathrm{b}$. As $\mathrm{T}$ gets longer the former fraction becomes insignificantly small and may be omitted. 


\subsection{Initial Test Measurements with Cf Source}

Multiple test measurements using the NIST-traceable ${ }^{252} \mathrm{Cf}$ neutron source "Cf-2" were performed with the test drum at varying standoff distances of the slabs ranging from 36 to 48 inches, and the slabs at various elevations ranging from $8-14$ inches in order to determine the optimum measurement configuration. The source was placed at three height levels (top, middle and bottom) in four tubes (T1, T2, T3 and T4) of the drum (see Figure 3.1). The source height is about one inch, thus measurements on the chosen vertical positions provided extreme minimum and maximum responses. As a result of these tests the final configuration with the slabs elevated at 11 inches from the ground and spread 43 inches apart (see Figure 3.2) was found as a compromise between variations in axial and azimuthal response profiles and absolute detection efficiency. The data obtained in several measurement sessions are summarized in Tables 3.1. and 3.2 .

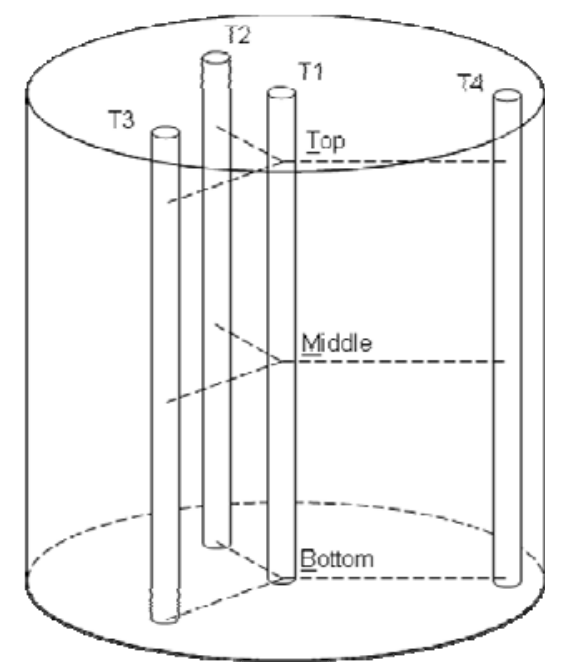

Figure 3.1. Source positions in the test drum 


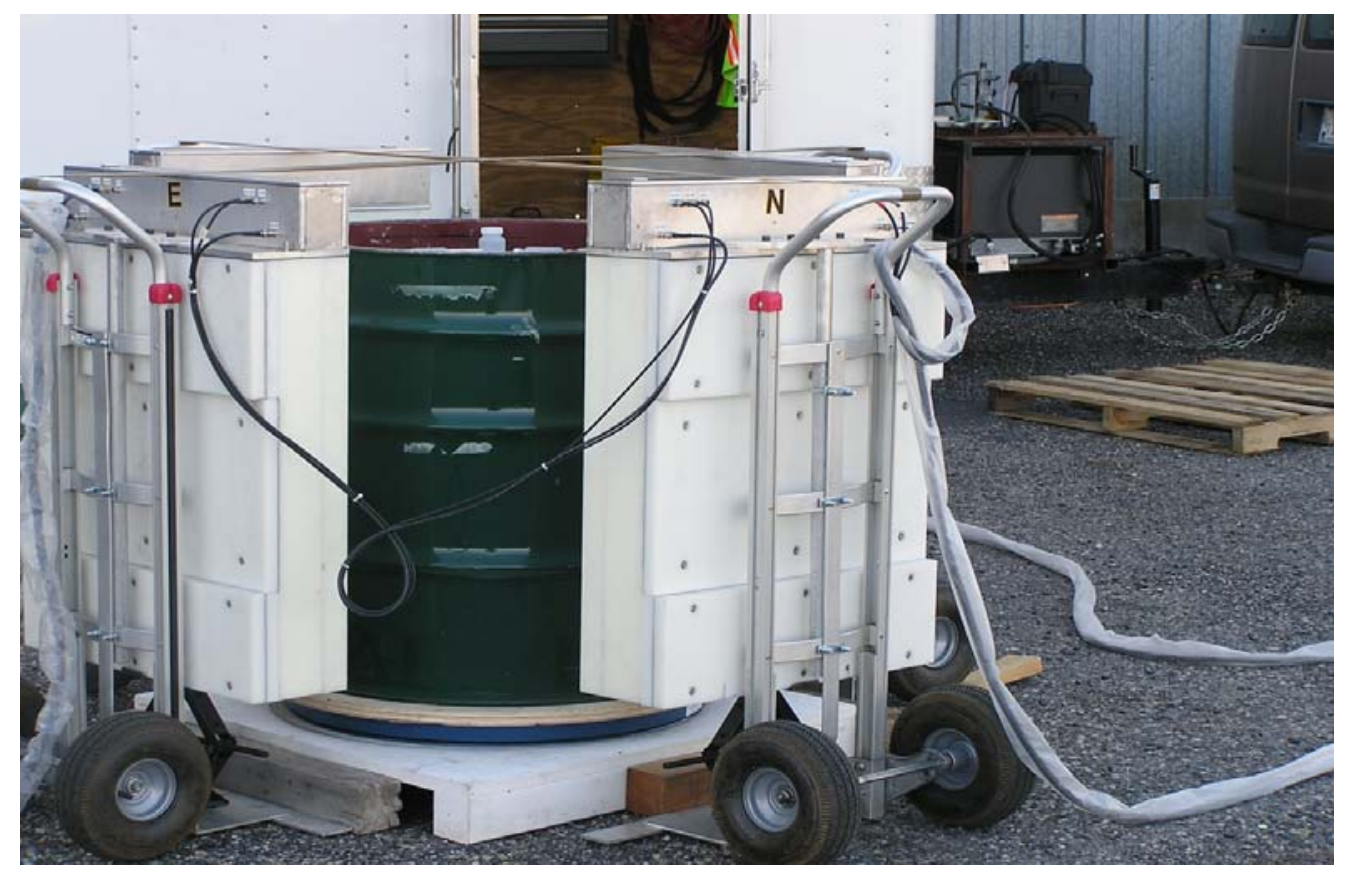

Figure 3.2. Measurements of the test drum with ${ }^{252} \mathrm{Cf}$ source inside

Table 3.1. Spatial responses for chosen 43" x 43" configuration

\begin{tabular}{|l|c|c|c|c|c|c|c|c|}
\hline \multirow{5}{*}{ Tube } & \multicolumn{5}{|c|}{ Singles [1/s] } & \multicolumn{4}{c|}{ Doubles [1/s] } \\
\cline { 2 - 8 } & $\mathrm{T} 1$ & $\mathrm{~T} 2$ & $\mathrm{~T} 3$ & $\mathrm{~T} 4$ & $\mathrm{~T} 1$ & $\mathrm{~T} 2$ & $\mathrm{~T} 3$ & $\mathrm{~T} 4$ \\
\hline \multirow{5}{*}{ Top } & 1357.048 & 1311.278 & 1467.376 & 1581.011 & 54.567 & 49.976 & 64.040 & 74.242 \\
& 1328.512 & 1363.897 & 1561.600 & 1585.940 & 51.772 & 53.996 & 73.643 & 75.361 \\
& 1254.745 & 1369.463 & & 1769.775 & 46.243 & 54.146 & & 91.914 \\
& & & & 1428.808 & & & & 61.363 \\
& & & & 1543.138 & & & & 69.477 \\
& & & & 1376.526 & & & & 56.831 \\
\hline \multirow{5}{*}{ Middle } & 2070.309 & 2177.711 & 2274.363 & 2400.351 & 126.715 & 141.069 & 151.791 & 175.373 \\
& 2054.863 & 2190.586 & 2337.323 & 2332.709 & 127.459 & 141.264 & 161.540 & 162.428 \\
& & 2200.258 & & 2134.450 & 124.776 & 148.183 & & 136.359 \\
& & & & 2519.435 & & & & 188.348 \\
& & & & 2703.778 & & & & 218.683 \\
\hline \multirow{5}{*}{ Bottom } & 1438.232 & 1463.612 & 1388.624 & 1410.477 & 61.188 & 64.159 & 55.970 & 59.937 \\
& 1465.354 & 1448.052 & 1391.699 & 1350.099 & 62.382 & 60.999 & 56.890 & 55.297 \\
& 1435.751 & 1422.041 & & 1443.849 & 58.731 & 59.676 & & 58.788 \\
& & & & 1496.883 & & & & 64.020 \\
\hline
\end{tabular}


Table 3.2. Averaged spatial responses for chosen 43 " x 43 " configuration

\begin{tabular}{|l|r|r|r|r|r|r|r|r|}
\hline \multicolumn{1}{|c|}{ Averaged for each position } \\
\hline Top & 1313 & 1348 & 1515 & 1548 & 51 & 53 & 69 & 72 \\
\hline Middle & 2064 & 2190 & 2306 & 2418 & 126 & 144 & 157 & 176 \\
\hline Bottom & 1446 & 1445 & 1390 & 1425 & 61 & 62 & 56 & 60 \\
\hline \multicolumn{10}{|c|}{ Averaged for each level } \\
\hline Top & 1431 & 61 & 151 \\
\hline Middle & 2244 & 60 \\
\hline Bottom & 1427 \\
\hline \multicolumn{7}{|c|}{$1866 \pm 319(17.1 \%)$} \\
\hline Overall
\end{tabular}

Since count rates obtained in the middle plane gave the maximum and those on the top and bottom the lowest, the overall average values and their uncertainties were determined based on the range of the data from the "averaged for each position" section of the table. For a random source position the probability distribution of the data is considered to be rectangular. Therefore, the overall average value and its standard uncertainty ${ }^{\dagger}$ [7] are calculated using the formulae below.

$$
\begin{aligned}
& <\mathrm{CR}>=\left(\mathrm{CR}_{\mathrm{MAX}}+\mathrm{CR}_{\mathrm{MIN}}\right) / 2 \\
& \Delta<\mathrm{CR}>=\left[\left(\mathrm{CR}_{\mathrm{MAX}}-\mathrm{CR}_{\mathrm{MIN}}\right) / 2\right] / \sqrt{ } 3
\end{aligned}
$$

Note that ratio $(\Delta<\mathrm{CR}>/<\mathrm{CR}>)$ represents relative systematic uncertainty of spatial detection efficiency, $\delta_{S}$, identified in equation $(2.2 \mathrm{~A})$

The neutron yield of Cf-2 Source on September 30, 2007 was 3.6 $10^{4}$ neutrons per second. Using the decay-corrected yield of the source and the foregoing singles count rate the detection efficiency of the measurement system for the chosen configuration was determined to be $5.3 \%$.

\footnotetext{
${ }^{\dagger}$ The standard uncertainty is equivalent to one standard deviation and is a key quantity in the combination of uncertainties.
} 


\subsection{Method Demonstration}

\subsection{Initial Cf source based calibration}

According to equations of the point model in neutron coincidence counting [8] the observed doubles count rate from a ${ }^{252} \mathrm{Cf}$ source (no multiplication and (alpha,n) production) can be expressed as follows:

$$
D^{C f}=F^{C f} \cdot \varepsilon^{2} \cdot f_{d} \cdot \frac{v_{S 2}^{C f}}{2}
$$

where $F^{C f} \quad$ - fission rate of a ${ }^{252} \mathrm{Cf}$ source, in turn

$$
F^{C f}=\frac{Y}{v_{S 1}^{C f}},
$$

$Y \quad-$ yield of the source and

$v_{S 1} \quad-$ the first factorial moment of multiplicity distribution of spontaneous fission $\left(v_{S I}{ }^{\mathrm{Cf}-252}=3.757 ; v_{S I}{ }^{\mathrm{Pu}-240}=2.156\right)[9]$

$\varepsilon \quad-$ detection efficiency

$f_{d} \quad-$ doubles gate fraction

$v_{S 2} \quad-$ the second factorial moment of multiplicity distribution of spontaneous fission

$$
\left(v_{S 2}{ }^{\mathrm{Cf}-252}=11.962 ; v_{S 2}{ }^{\mathrm{Pu}-240}=3.825\right)[9]
$$

Then $F^{P u}$ - fission rate of ${ }^{240} \mathrm{Pu}$ equivalent to $D^{C f}$ may be expressed as

$$
F^{P u}=\frac{2 \cdot D^{C f}}{\varepsilon^{2} \cdot f_{d} \cdot v_{S 2}^{P u}}=\frac{Y \cdot v_{S 2}^{C f} \cdot 2}{v_{S 1}^{C f} \cdot 2 \cdot v_{S 2}^{P u}} \cdot \frac{\left[f_{d} \cdot \varepsilon^{2}\right]^{C f}}{\left[f_{d} \cdot \varepsilon^{2}\right]^{P u}}
$$

If effective mass of ${ }^{240} \mathrm{Pu}$ can be determined as ${ }^{240} m_{\text {eff }}=F^{P u} / g$,

where $\boldsymbol{g}-$ specific fission rate of ${ }^{240} \mathrm{Pu}\{473.5$ fissions $/ \mathrm{s} / \mathrm{g}\}$

Then

$$
{ }^{240} m_{e f f}=\frac{1}{g} \cdot \frac{Y \cdot v_{S 2}^{C f}}{v_{S 1}^{C f} \cdot v_{S 2}^{P u}} \cdot \frac{\left[f_{d} \cdot \varepsilon^{2}\right]^{C f}}{\left[f_{d} \cdot \varepsilon^{2}\right]^{P u}}
$$


On the other hand, a calibration factor for a neutron coincidence system is $\mathrm{D} /{ }^{240} \mathrm{~m}_{\mathrm{eff}}$. Hence, assuming that the ratio of brackets in equations (4.1.2) and (4.1.3) is approximately unity the calibration factor can be estimated as

$$
b_{D}=\frac{g \cdot D^{C f}}{Y} \cdot \frac{v_{S 1}^{C f} \cdot v_{S 2}^{P u}}{v_{S 2}^{C f}}
$$

Estimation of the calibration factor for singles count rate can be done even simpler using the following equation:

$$
b_{S}=\varepsilon \cdot g \cdot v_{S 1} \cdot(1+\alpha)
$$

where $\alpha \quad-$ alpha parameter which is the ratio between neutron production rate due to (alpha,n) reaction(s) in a sample and that from spontaneous fission.

However, the calibration factor accuracy depends on correctness of assumed alpha parameter of plutonium-bearing material.

The source equivalent ${ }^{240} \mathrm{Pu}$ mass calibration factors determined through equations (4.1.3), (4.1.4), (4.1.5) are presented in Table 4.1.1.

Table 4.1.1. Calibration factors for singles and doubles based on ${ }^{252} \mathrm{Cf}$ measurements

\begin{tabular}{|l|c|c|c|}
\hline Parameter/Factor & \multicolumn{2}{|c|}{ Singles $\left(\mathrm{b}_{\mathrm{S}}\right)$} & Doubles $\left(\mathrm{b}_{\mathrm{D}}\right)$ \\
\hline Alpha Ratio (assumption) & $\begin{array}{c}\sim 0.8 \\
\left.\text { (pure } \mathrm{PuO}_{2}\right) \\
\text { conservative }\end{array}$ & $\begin{array}{c}\sim 2.4 \\
\left(\mathrm{PuO}_{2} \text { with } \mathrm{DE}^{\S}\right) \\
\text { likely. }\end{array}$ & N/A \\
\hline Equivalent ${ }^{240} \mathrm{Pu}$ mass [g] & \multicolumn{2}{c|}{62.24} & $1.83 \pm 0.53$ \\
\hline $\begin{array}{l}\text { Calibration factor value } \\
\pm 1 \text { standard deviation } \\
{\left[\text { counts/s/g of }{ }^{240} \mathrm{Pu}\right]}\end{array}$ & $96.8 \pm 16.5$ & $182.8 \pm 31.2$ & \\
\hline
\end{tabular}

Thus using the foregoing calibration factors the obtained singles and doubles count rates can be converted to mass of ${ }^{240} \mathrm{Pu}_{\mathrm{eff}}$ as follows:

$$
{ }^{240} \mathrm{~m}_{\text {eff(S) }}=\mathrm{S} / \mathrm{b}_{\mathrm{S}} \quad \text { and } \quad{ }^{240} \mathrm{~m}_{\mathrm{eff}(\mathrm{D})}=\mathrm{D} / \mathrm{b}_{\mathrm{D}}, \quad \text { respectively. }
$$

\footnotetext{
${ }^{\S}$ Diatomaceous earth
} 
Their corresponding uncertainties are then:

$$
\begin{aligned}
& \Delta\left({ }^{240} m_{e f f}\right)_{(S)}={ }^{240} m_{e f f(S)} \cdot \sqrt{\left(\frac{\sigma S}{S}\right)^{2}+\left(\frac{\delta b_{S}}{b_{S}}\right)^{2}} \text { and } \\
& \Delta\left({ }^{240} m_{e f f(D)}=m_{e f f(D)} \cdot \sqrt{\left(\frac{\sigma D}{D}\right)^{2}+\left(\frac{\delta b_{D}}{b_{D}}\right)^{2}}\right.
\end{aligned}
$$

where $\mathrm{S} \quad-$ singles count rate;

D - doubles count rate.

Equations (4.1.6) and (4.1.7) resemble those (2.2) and (2.2A). Subsequent calculations to obtain total mass of plutonium and hence TRU concentration are identical for both singles and doubles and are performed per equations in section 2 . 


\subsection{Method Detection Limit}

Counting times of background measurements ranged from 600 to 1800 seconds. Background measurements repeated several times over the testing period showed good reproducibility. Although the counting uncertainty of singles of an individual measurement was about $0.12 \mathrm{c} / \mathrm{s}$ the uncertainty calculation based on multiple measurements almost doubled. For doubles the opposite behavior was observed; counting uncertainty of an individual measurement was about $0.016 \mathrm{c} / \mathrm{s}$ and that calculated based on multiple measurements was half of that value. Several measurements were also performed with the blank test drum (with no sources) in order to check for possible effects of the drum volume and matrix on the background count rates. The summarized data are shown in Table 4.2.1. The obvious difference in the countrates with and without the drum can be attributed to increased scattering and spallation effects in the drum matrix. Thus the detection limits were calculated based on the "baseline" countrates obtained with the blank drum in place.

Table 4.2.1. Background/Baseline measurements at T-Plant

\begin{tabular}{|l|c|c|}
\hline Parameter & Singles [c/s] & Doubles [c/s] \\
\hline \multicolumn{2}{|c|}{ Averaged over testing exercise (multiple measurements on several days) } \\
\hline With the blank test drum in place (no sources) & $15.18 \pm 0.22$ & $0.094 \pm 0.006$ \\
\hline Without the drum & $14.55 \pm 0.42$ & $0.014 \pm 0.006$ \\
\hline Difference & $0.63 \pm 0.48$ & $0.080 \pm 0.008$ \\
\hline
\end{tabular}

Taking the highest values of uncertainty for singles and doubles, $0.22 \mathrm{c} / \mathrm{s}$ and $0.016 \mathrm{c} / \mathrm{s}$, respectively, one can estimate MDL for the count rates ("drum background" corrected ) using formula (2.6) and then using formulae (4.1.6) (or (2.2)) and (2.3):

\begin{tabular}{|c|c|c|c|}
\hline \multirow[t]{2}{*}{ Singles: } & $1.02 \mathrm{c} / \mathrm{s}$ & $\rightarrow$ & $0.17 \mathrm{~g}$ of weapon-grade $\mathrm{Pu}$ (conservative \\
\hline & & or & $0.09 \mathrm{~g}$ of weapon-grade $\mathrm{Pu}$ (likely) \\
\hline Doubles: & $0.074 \mathrm{c} / \mathrm{s}$ & $\rightarrow$ & $0.66 \mathrm{~g}$ of weapon-grade $\mathrm{Pu}$ \\
\hline
\end{tabular}

The net weight of the majority ( $>95 \%$ ) of these 110 gallon "puck" drums exceeded 300 kilograms with about 350 kilograms as the average. Thus the conservative estimates (from the Pu mass values above and for net weight of $300 \mathrm{~kg}$ ) of the minimum detectable concentration (MDC) would be obtained using equations (2.4) and (2.5):

Singles: $\quad 54 \mathrm{nCi} / \mathrm{g}$ (conservativen)

or $\quad 28 \mathrm{nCi} / \mathrm{g}($ likely)

Doubles: $\quad 207 \mathrm{nCi} / \mathrm{g}$

Even the conservative estimate of an MDC using a singles count rate will meet the criteria to distinguish the drums between LLW and TRU. 


\subsection{Routine Measurement Approach}

Each drum measurement combined four separate 10-minute long counts; thus the total measurement time was 40 minutes. A measured drum was rotated on a turntable by 135 degrees between the separate counts (see Figure 4.3.1). Measurement results were obtained as an average of the values from all counts with the counting uncertainty calculated as a standard deviation. Total measurement uncertainty was calculated according to the algorithm described in Section 2.
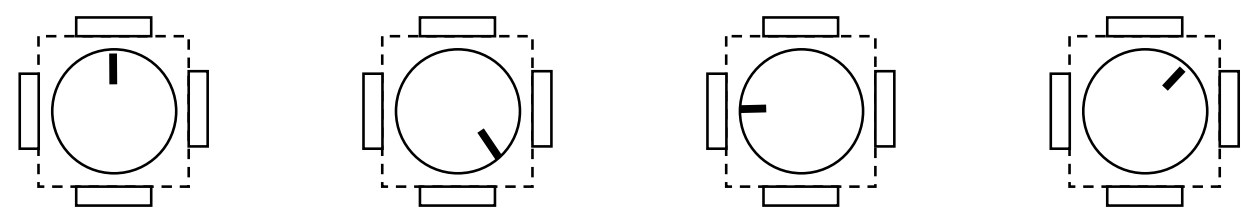

Figure 4.3.1. Drum Counting Positions

After successful completion of a daily performance check measurement, the current baseline (with blank "puck" drum in place) countrate value and its uncertainty was obtained before measurements of real "puck" drums.

The result obtained from counting a drum was compared against the detection limit values (derived from blank "puck" drum measurements) as follows:

- If the singles count rate was less than the corresponding detection limit, then the singles detection limit value was assigned to the drum content and used for the concentration calculation.

- If the singles count rate was higher than the corresponding detection limit, but the calculated TRU concentration was less than $100 \mathrm{nCi} / \mathrm{g}$ for the net waste weight of the drum then the drum was classified as "LLW".

- If the TRU concentration calculated based on the singles count rate was higher than $100 \mathrm{nCi} / \mathrm{g}$ for the net waste weight of the drum then the drum was considered "Suspect TRU" waste. If doubles count rates were below the corresponding detection limit then the doubles detection limit was used to assign the upper bounding value for the content and concentration.

- If doubles count rates were higher than the corresponding detection limit then the drum content and concentration was assigned based on this value. 


\subsection{Verification Measurements With Pu Standards}

\subsection{Pu Standards Data}

A series of measurements intended to verify the measurement method and revise the initial calibration were performed at the WRAP facility with the test "puck" drum and NIST-traceable plutonium standards. Isotopic and mass values for $\mathrm{Pu}$ standards used in this exercise are presented in tables 5.1.1 and 5.1.2.

Table 5.1.1. Isotopic Content of Pu standards

\begin{tabular}{|l|r|r|}
\hline \multirow{2}{*}{ Nuclide } & \multicolumn{2}{|c|}{ Content $[\mathrm{wt} \%$ on date } \\
\cline { 2 - 3 } & \multicolumn{1}{|c|}{$09 / 21 / 1999$} & \multicolumn{1}{c|}{$12 / 08 / 2007$} \\
\hline${ }^{238} \mathrm{Pu}$ & $0.014 \pm 0.005$ & $0.013 \pm 0.005$ \\
\hline${ }^{239} \mathrm{Pu}$ & $93.808 \pm 0.015$ & $93.873 \pm 0.015$ \\
\hline${ }^{240} \mathrm{Pu}$ & $5.939 \pm 0.007$ & $5.939 \pm 0.007$ \\
\hline${ }^{241} \mathrm{Pu}$ & $0.185 \pm 0.009$ & $0.121 \pm 0.006$ \\
\hline${ }^{242} \mathrm{Pu}$ & $0.054 \pm 0.003$ & $0.054 \pm 0.003$ \\
\hline${ }^{241} \mathrm{Am}$ & $0.11289 \pm 0.00003$ & $0.1755 \pm 0.00005$ \\
\hline & & \\
${ }^{240} \mathrm{Pu}$ eff & $6.07 \pm 0.02$ & $6.06 \pm 0.02$ \\
\hline
\end{tabular}

Table 5.1.2. Mass values of $\mathrm{Pu}$ standards

\begin{tabular}{|r|c|c|c|}
\hline \multirow{2}{*}{ On date } & $09 / 21 / 1999$ & \multicolumn{2}{c|}{$12 / 08 / 2007$} \\
\cline { 2 - 4 } & \multicolumn{2}{|c|}{ Total $\mathrm{Pu}[\mathrm{g}]$} & ${ }^{240} \mathrm{Pu}_{\mathrm{eff}}[\mathrm{g}]$ \\
\hline Pu Standard \#1 & $0.09710 \pm 0.00011$ & $0.09701 \pm 0.00011$ & $0.00588 \pm 0.00002$ \\
\hline Pu Standard \#2 & $0.20038 \pm 0.00021$ & $0.20020 \pm 0.00021$ & $0.01214 \pm 0.00005$ \\
\hline Pu Standard \#3 & $0.50831 \pm 0.00051$ & $0.50785 \pm 0.00051$ & $0.03079 \pm 0.00013$ \\
\hline Pu Standard \#4 & $0.51523 \pm 0.00051$ & $0.51477 \pm 0.00051$ & $0.03121 \pm 0.00013$ \\
\hline Pu Standard \#5 & $1.01534 \pm 0.00098$ & $1.01443 \pm 0.00098$ & $0.06151 \pm 0.00025$ \\
\hline Pu Standard \#6 & $5.04299 \pm 0.00474$ & $5.03845 \pm 0.00474$ & $0.30550 \pm 0.00124$ \\
\hline Pu Standard \#7 & $5.01168 \pm 0.00472$ & $5.00717 \pm 0.00472$ & $0.30360 \pm 0.00123$ \\
\hline
\end{tabular}




\subsection{Baseline Measurements at WRAP}

The first day at WRAP was spent finding an appropriate measurement location. Very high background values (over ten times higher than those obtained at T-Plant) were observed at the initially planned measurement location. This forced relocation to an alternative place. Satisfactory count rates of ambient background were obtained on a side of the parking lot by building $2720 \mathrm{~W}$, although the choice of measurement location (being outside of the controlled area and at a distance from the material storage) impacted practicality of the test measurements for WRAP operations staff.

Multiple measurements of ambient background and the blank "puck" drum were conducted to establish the baseline value for the test measurements. The data obtained on all three days are summarized in Table 5.2.1. As it can be seen from the table, the data obtained on different dates are in good agreement. The negative difference in the singles count rate between ambient background and the blank "puck" drum may be attributed to, so called, background suppression effect.

Table 5.2.1. Baseline count rates observed at WRAP during the test measurements

\begin{tabular}{|c|c|c|c|c|}
\hline & Date & $\begin{array}{c}\text { Ambient Background } \\
{[\mathrm{c} / \mathrm{s}]}\end{array}$ & $\begin{array}{c}\text { Blank “puck” drum } \\
{[\mathrm{c} / \mathrm{s}]}\end{array}$ & $\begin{array}{c}\text { Difference } \\
{[\mathrm{c} / \mathrm{s}]} \\
\end{array}$ \\
\hline \multirow{4}{*}{$\frac{\mathscr{\theta}}{000}$} & $12 / 5 / 07$ & $32.922 \pm 0.154$ & $31.940 \pm 0.152$ & $-0.982 \pm 0.216$ \\
\hline & $12 / 7 / 07$ & $32.753 \pm 0.207$ & $31.581 \pm 0.259$ & $-1.172 \pm 0.332$ \\
\hline & $12 / 11 / 07$ & $30.847 \pm 0.256$ & $29.873 \pm 0.173$ & $-0.974 \pm 0.309$ \\
\hline & \multicolumn{3}{|r|}{ Averaged: } & $-1.043 \pm 0.112$ \\
\hline \multirow{4}{*}{$\frac{\frac{\tilde{\theta}}{0}}{\frac{0}{0}}$} & $12 / 5 / 07$ & $0.018 \pm 0.011$ & $0.131 \pm 0.013$ & $0.113 \pm 0.016$ \\
\hline & $12 / 7 / 07$ & $0.020 \pm 0.017$ & $0.123 \pm 0.030$ & $0.104 \pm 0.035$ \\
\hline & $12 / 11 / 07$ & $0.027 \pm 0.024$ & $0.123 \pm 0.030$ & $0.097 \pm 0.039$ \\
\hline & \multicolumn{3}{|r|}{ Averaged: } & $0.104 \pm 0.009$ \\
\hline
\end{tabular}




\subsection{Measurements with Pu Standards}

The primary purpose of the measurements with $\mathrm{Pu}$ standards was to verify if the detection limit identified was below $100 \mathrm{nCi} / \mathrm{g}$; which was equivalent to about $0.3 \mathrm{~g}$ of weapon-grade plutonium for selected net waste weight of $300 \mathrm{~kg}$. For this measurement the plutonium standards of $0.1 \mathrm{~g}$ and $0.2 \mathrm{~g}$ were loaded at the top of T1 tube and at the middle of T3 tube, respectively. The observed singles countrate was $2.404 \pm 0.327 \mathrm{c} / \mathrm{s}$ which was almost twice as high as the determined detection limit of $1.301 \mathrm{c} / \mathrm{s}$. The doubles count rate of $0.047 \pm 0.009 \mathrm{c} / \mathrm{s}$ was less than half of the corresponding detection limit of $0.112 \mathrm{c} / \mathrm{s}$. Both results were in good agreement with predicted values for detection limits.

The next activity - measurements with a higher mass of plutonium - was intended to revise calibration factors obtained in the initial exercise with the californium source. The summarized measurement results (with blank "puck" drum count rates subtracted) are presented in Table 5.3.1 and plotted in Figures 5.3.1 and 5.3.2. The highest mass point was used to fit a linear function through the origin point. This equation has been used as a new calibration curve. The medium mass points were used as confirmation data.

Table 5.3.1. Results of measurements with Pu standards

\begin{tabular}{|c|c|c|c|c|c|c|}
\hline \multirow{2}{*}{$\begin{array}{c}\text { Pu mass } \\
\mathrm{g} \\
\end{array}$} & \multirow{2}{*}{$\begin{array}{c}{ }^{240} \mathrm{Pu}_{\text {eff }} \\
\mathrm{g} \\
\end{array}$} & \multirow{2}{*}{$\begin{array}{c}\text { Loading } \\
\text { Location } \\
\text { Sensitivity* } \\
\end{array}$} & \multicolumn{2}{|c|}{ Singles } & \multicolumn{2}{|c|}{ Doubles } \\
\hline & & & $\mathrm{s}^{-1}$ & $\left(\mathrm{~s} \cdot \mathrm{g}{ }^{240} \mathrm{Pu}_{\mathrm{eff}}\right)^{-1}$ & $\mathrm{~s}^{-1}$ & $\left(\mathrm{~s} \cdot \mathrm{g}^{240} \mathrm{Pu}_{\mathrm{eff}}\right)^{-1}$ \\
\hline 0.30 & 0.018 & average & $2.40 \pm 0.33$ & 133.5 & $0.05 \pm 0.01$ & 2.58 \\
\hline 10.05 & 0.609 & average & $88.58 \pm 0.63$ & 147.6 & $1.29 \pm 0.06$ & 2.15 \\
\hline 6.06 & 0.367 & above average & $57.73 \pm 0.65$ & 160.4 & $0.89 \pm 0.05$ & 2.46 \\
\hline 2.04 & 0.124 & below average & $16.10 \pm 0.22$ & 134.2 & $0.21 \pm 0.02$ & 1.78 \\
\hline 2.04 & 0.124 & above average & $19.68 \pm 0.48$ & 164.0 & $0.20 \pm 0.02$ & 1.65 \\
\hline & & & Average: & $143.9 \pm 12.7$ & Average: & $2.2 \pm 0.4$ \\
\hline
\end{tabular}

* - based on results of the initial testing (see table 3.1)

The newly obtained (revised) calibration functions were

a) Singles $[\mathrm{c} / \mathrm{s}]=145.42( \pm 0.36) \cdot\left[{ }^{240} \mathrm{Pu}_{\mathrm{eff}}\right.$ grams $]$

and

b) Doubles $[\mathrm{c} / \mathrm{s}]=2.114( \pm 0.014) \cdot\left[{ }^{240} \mathrm{Pu}_{\mathrm{eff}}\right.$ grams $]$. 


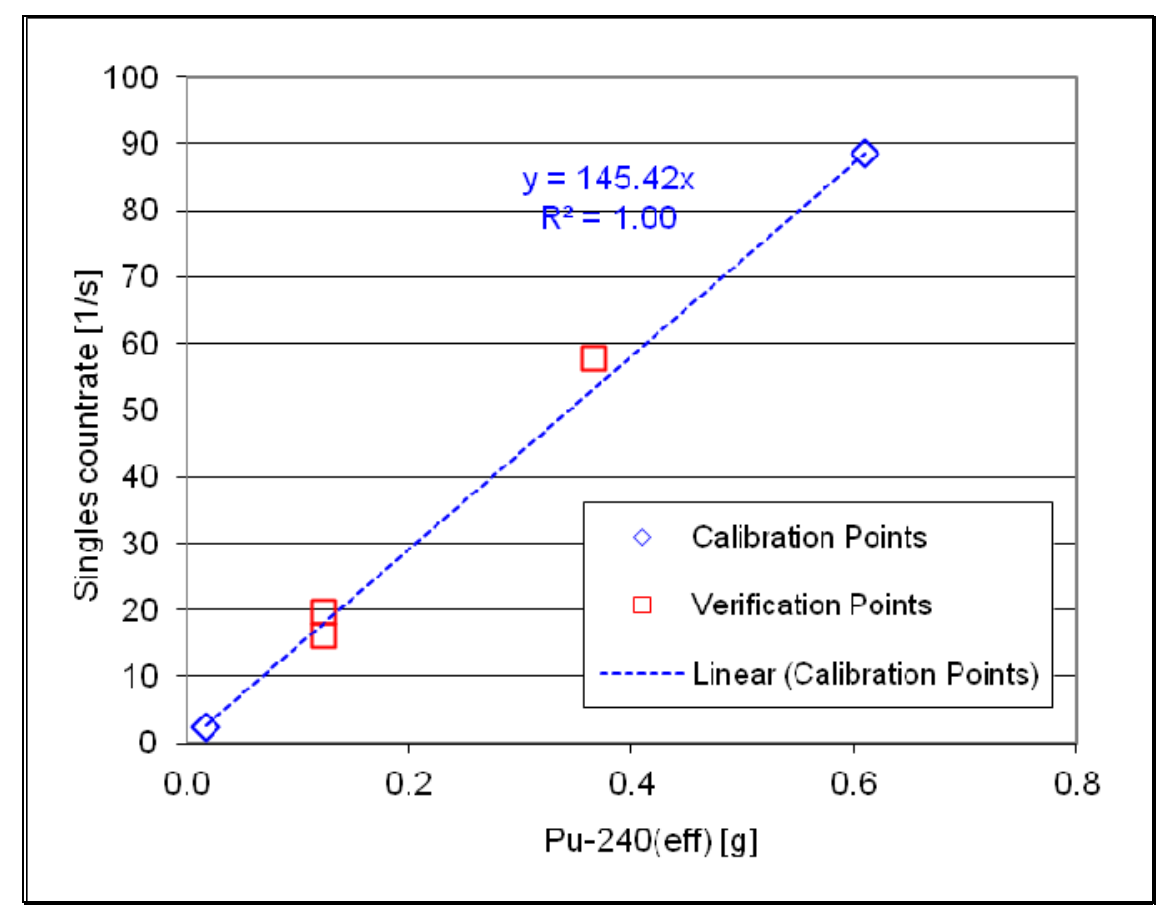

Figure 5.3.1. Singles Count Rate results

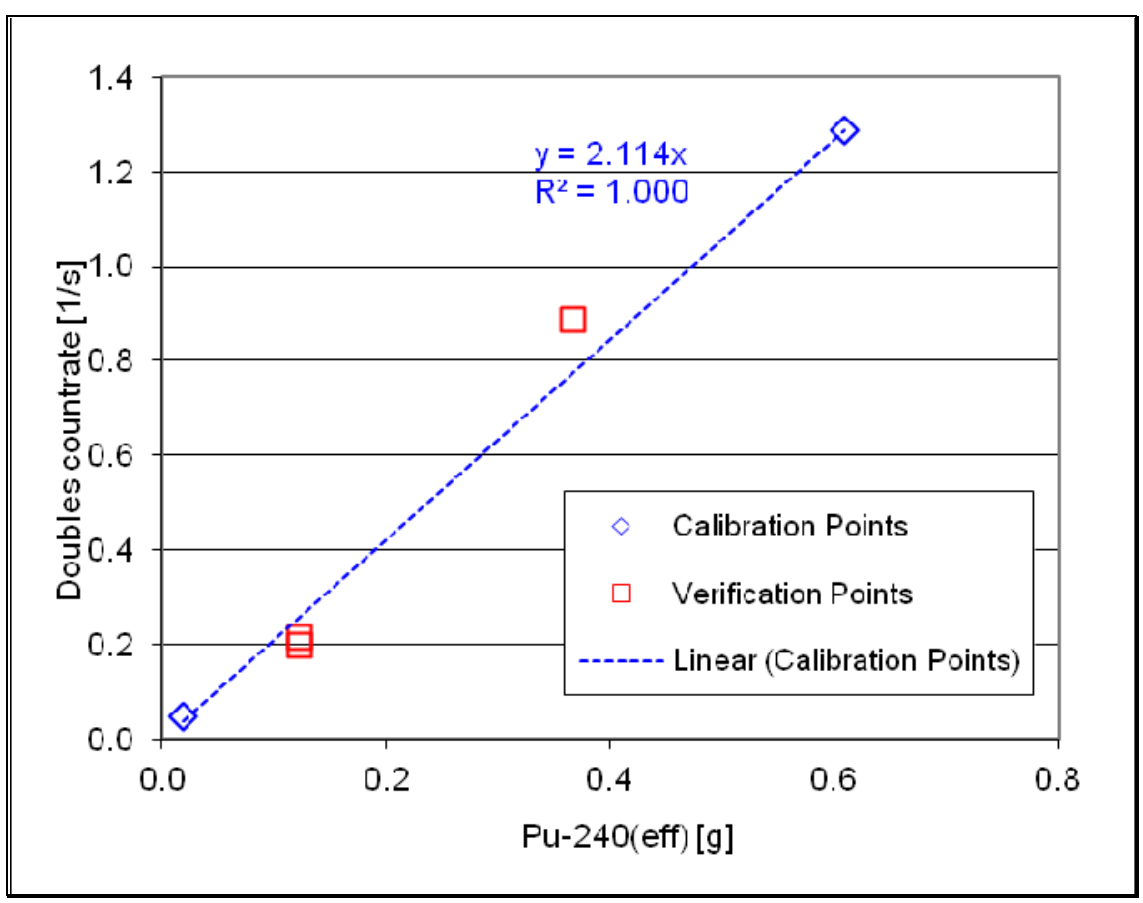

Figure 5.3.2. Doubles Count Rate results 
Using the revised calibration factors, the medium mass results were analyzed and compared to the acceptance criteria: the results should have been within $\pm 30 \%$ of the known or accepted Pu mass value. The results with associated uncertainties are presented in Table 5.3.2. As it can be seen from the table, all calibration confirmation measurements were within $\pm 30 \%$ of corresponding accepted values (and within \pm 1 standard deviation).

Table 5.3.2. Confirmation of Calibration factors revised

\begin{tabular}{|c|c|c|c|c|}
\hline \multirow{2}{*}{ Known ${ }^{240} \mathrm{Pu}_{\text {eff }}$} & \multicolumn{2}{|c|}{ Singles } & \multicolumn{2}{c|}{ Doubles } \\
\cline { 2 - 5 } & Assayed ${ }^{240} \mathrm{Pu}_{\text {eff }}$ & Difference & Assayed ${ }^{240} \mathrm{Pu}_{\text {eff }}$ & Difference \\
\hline \hline $\mathrm{g}$ & $\mathrm{g}$ & $\%$ & $\mathrm{~g}$ & $\%$ \\
\hline 0.367 & $0.397 \pm 0.068(17.1 \%)$ & $8.2 \%$ & $0.419 \pm 0.136(32.3 \%)$ & $14.3 \%$ \\
\hline 0.124 & $0.111 \pm 0.019(17.2 \%)$ & $-10.3 \%$ & $0.101 \pm 0.034(33.5 \%)$ & $-18.3 \%$ \\
\hline 0.124 & $0.135 \pm 0.023(17.3 \%)$ & $9.6 \%$ & $0.093 \pm 0.032(33.8 \%)$ & $-24.4 \%$ \\
\hline
\end{tabular}




\subsection{Field Measurements}

\subsection{Alternative for Baseline Determination}

Once the measurement method had been demonstrated to meet requirements for distinguishing between LLW and TRU "puck" drums, the neutron slab system was promptly deployed at TPlant to count hundreds of "puck" drums already accumulated. However, at the very beginning of the measurement campaign it became necessary to find an alternative for the baseline count rate measurements because the blank test "puck" drum was to be transferred to WRAP for SuperHENC calibration and baseline measurements.

The series of ambient background and the blank "puck" drum measurements were performed in order to determine an average difference between the count rate values. The data are shown in Table 6.1.1. Then the difference value was applied to correct a current ambient background value - to estimate the baseline value. On one hand, this "maneuver" allowed dispensing the need to have the blank test "puck" drum for baseline measurements, but on the other hand, propagated uncertainty of the background value elevated the detection limit from $25-35$ up to $70-80 \mathrm{nCi} / \mathrm{g}$.

Table 6.1.1. Difference between blank test drum and ambient background counts

\begin{tabular}{|r|c|c|c|c|}
\hline Assay Date & Singles & S Sigma & Doubles & D Sigma \\
\hline \hline $11 / 13 / 2007$ & $\mathrm{c} / \mathrm{s}$ & $\mathrm{c} / \mathrm{s}$ & $\mathrm{c} / \mathrm{s}$ & $\mathrm{c} / \mathrm{s}$ \\
\hline $2 / 6 / 2008$ & 0.628 & 0.476 & 0.080 & 0.008 \\
\hline $1 / 16 / 2008$ & 0.393 & 0.329 & 0.076 & 0.021 \\
\hline $1 / 22 / 2008$ & 0.608 & 0.168 & 0.069 & 0.015 \\
\hline $1 / 23 / 2008$ & 0.763 & 0.258 & 0.069 & 0.006 \\
\hline $1 / 24 / 2008$ & 1.019 & 0.207 & 0.063 & 0.022 \\
\hline $2 / 5 / 2008$ & 1.163 & 0.189 & 0.094 & 0.016 \\
\hline $2 / 11 / 2008$ & 0.853 & 0.221 & 0.085 & 0.021 \\
\hline $2 / 12 / 2008$ & 1.340 & 0.136 & 0.082 & 0.014 \\
\hline $2 / 14 / 2008$ & -0.282 & 0.663 & 0.093 & 0.025 \\
\hline $2 / 15 / 2008$ & 0.346 & 0.217 & 0.058 & 0.031 \\
\hline Average & 0.713 & 0.274 & 0.079 & 0.021 \\
\hline & & 0.452 & 0.077 & 0.012 \\
\hline
\end{tabular}




\subsection{Performance Evaluation}

A year after the beginning of the measurement campaign at T-Plant the mobile neutron slab system was brought to the WRAP facility in order to verify the calibration factors established for assaying of 110 gallon puck drums. The system performance was verified by measurements of the test drum loaded with $\mathrm{Pu}$ standards. The measurement results are summarized in Table 6.2.1. As it can be seen the differences between assayed and declared values of Pu mass for both singles and doubles were less than one standard deviation of measurement uncertainty.

Table 6.2.1. Results of verification measurements with Pu standards

\begin{tabular}{|c|c|c|c|c|c|}
\hline$\# \#$ & $\begin{array}{c}\text { Declared Pu mass } \\
{[\mathrm{g}]}\end{array}$ & \multicolumn{2}{|c|}{$\begin{array}{c}\text { Assayed Pu mass } \pm 1 \text { std. dev. } \\
{[\mathrm{g}]}\end{array}$} & \multicolumn{2}{|c|}{$\begin{array}{c}\text { Recovery [A/D] } \\
{[\%]}\end{array}$} \\
\cline { 2 - 5 } & & Singles & Doubles & Singles & Doubles \\
\hline \hline 1 & 1.02 & $1.05 \pm 0.19$ & $1.02 \pm 0.35$ & $103 \%$ & $100 \%$ \\
\hline 2 & 10.04 & $9.71 \pm 1.73$ & $9.25 \pm 3.05$ & $97 \%$ & $92 \%$ \\
\hline
\end{tabular}

Out of 352 drums assayed during the measurement campaign at T-Plant, only 31 were found to be "Suspect TRU" (two of them due to low net weight). Twenty five of these "Suspect TRU" drums were shipped to WRAP and assayed at the SuperHENC (stantionary trailer-based, high efficiency neutron counter) [10]. 21 out of these 25 were confirmed to be TRU [Brian Anderson, Personal Communication, January 5, 2011]. Thus the immediate sorting of the "puck" drums at T-Plant had provided just about $1 \%$ of "false positive" results.

Net counting time of a drum at the mobile neutron slab system was 40 minutes versus that of 30 minutes at the SuperHENC. However, taking into account process of drum loading/unloading the gross counting times of the measurement systems were comparable.

Overall, the performance of the mobile neutron slab system and measurement approach may be considered outstanding. 


\subsection{Conclusions}

The PNNL NDA Service Center developed and demonstrated a simple and relatively inexpensive method of assaying 110 gallon "puck" drums. The configurable neutron slab system was calibrated to distinguish between TRU and LLW drums. Sorting drums at T-Plant considerably reduced efforts associated with drum handling and shipping. The suggested measurement method proved to be reliable and very cost-effective.

Over a year-long period of time the mobile neutron system demonstrated impeccable and steady performance sorting out over 350 "puck" drums. Just four drums out of the assessed inventory were over classified which in turn provided additional evidence of the measurement method efficiency.

Even with such outstanding performance of the system additional improvements of the measurement process are believed to be possible and should be further investigated. Potential reduction of counting time would result in increased drum throughput and hence lower costs of the measurements. 


\subsection{References}

1. HNF-EP-0063 "Hanford Site Solid Waste Acceptance Criteria", Revision 15, February 2010.

2. ASTM C 1133 - 03, Standard Test Method for Nondestructive Assay of Special Nuclear Material in Low-Density Scrap and Waste by Segmented Passive Gamma-Ray Scanning.

3. ASTM C1316 - 01, Standard Test Method for Nondestructive Assay of Nuclear Material in Scrap and Waste by Passive-Active Neutron Counting Using a ${ }^{252} \mathrm{Cf}$ Shuffler.

4. ASTM C1493 - 01, Standard Test Method for Nondestructive Assay of Nuclear Material in Waste by Passive and Active Neutron Counting Using Differential Die-Away System.

5. ASTM C 1207 - 03, Standard Test Method for Nondestructive Assay of Plutonium in Scrap and Waste by Passive Neutron Coincidence Counting.

6. DOE/RL-96-68, Hanford Analytical Services Quality Assurance Requirements Document, Volume 4, Revision 3, Effective Date: 6/1/2007

7. Measurement Good Practice Guide No. 34, "Radiometric Non-Destructive Assay", ISSN 1368-6550, January 2003

8. N.Ensslin, W.C.Harker, M.S.Krick, D.C.Langner, M.M.Pickrell, J.E.Stewart, "Application Guide to Neutron Multiplicity Counting", Los Alamos National Laboratory Report, LA-13422-M, Novermber 1998.

9. N.Ensslin, Chapter 11 "The Origin of Neutron Radiation" in D.Reilly, N.Ensslin, and H.Smith, "Passive Nondestructive Assay of Nuclear Materials", United States Nuclear Regulatory Commission, Washington, DC, NUREG/CR-5550, 1991.

10. Naeem M. Abdurrahman, Alan P. Simpson and Steve Barber, "WIPP Certification of A New SuperHENC at Hanford for Assay of Transuranic Waste in Standard Waste Boxes", American Nuclear Society Winter Meeting, Washington, DC, November 13-17, 2005 


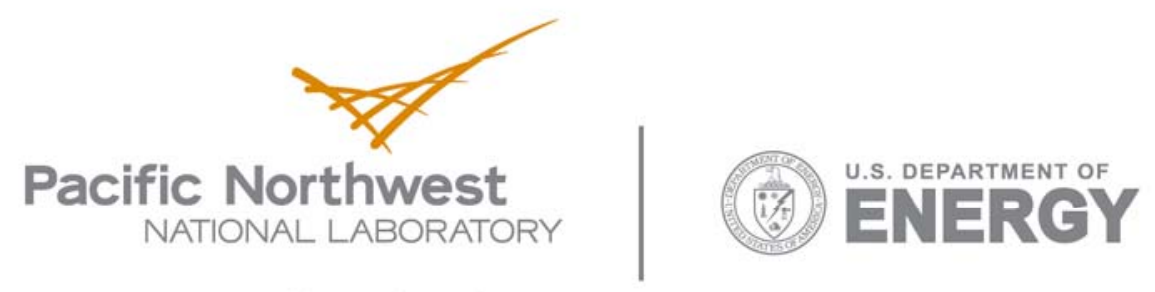

902 Battelle Boulevard

P.O. Box 999

Richland, WA 99352

1-888-375-PNNL (7665)

www.pnl.gov 